Sains Malaysiana 49(11)(2020): 2609-2623

http://dx.doi.org/10.17576/jsm-2020-4911-01

\title{
Intraspecific Phenotypic Variation in Nearly Threatened Mottled Nandus, Nandus nandus (Hamilton, 1822)
}

(Variasi Fenotip Intrakhusus Patung Belang Nandus yang Hampir Terancam, Nandus nandus (Hamilton, 1822))

\author{
Md. Sarower-E-Mahfuj, Md. Abdus Samad, Fee Faysal Ahmed, Md. Abdul Alim, Yosni BaKar \& Simon \\ KUMAR DAS*
}

\begin{abstract}
Understanding intraspecific phenotypic plasticity is a prerequisite of stock identification, evolutionary studies, sustainable utilization, and fishery conservation. In this study, intraspecific phenotypic plasticity was assessed in terms of the external features (i.e. meristic, morphometric, and truss-based morphometrics) of the wild Nandus populations from four freshwater sources in Southwestern Bangladesh. Fish samples were collected from Arial Kha River, Madaripur (AKRM, n=26); Nabaganga River, Jhenaidah (NRJ, $n=22)$; Bohnni Baor, Gopalganj (BBG, $n=26)$; and Dhakuria Beel, Jashore (DBJ, $n=22)$. Meristic, morphometric, and truss network data were subjected to one-way ANOVA followed by post hoc (Tukey-HSD) test. The meristic counts of all the samples demonstrated significant differences only in one of the six characters. By contrast, significant differences were observed in 8 morphometric characters and 31 truss network data from 16 morphometric characters and 35 truss network data, respectively. Principal component (PCA) and canonical variate analyses (CVA) were also performed on morphometric and truss-based network data. Meristic and morphometric results from PCA and CVA showed that populations were completely intermingled, forming a compact cluster within intrapopulation levels, while truss morphometric characters formed a separate cluster. Three dendrograms independently based on phenotypic relationships among the individuals of the four populations also confirmed the absence of phenotypic differentiation among the population due to clustering of different groups. The baseline information resulting from the current study would be useful for genetic studies and further in situ conservation of Nandus populations in Bangladesh.
\end{abstract}

Keywords: Canonical variate analysis; freshwater; morphometric; meristic; nandus; principle component analysis; Truss morphometry

ABSTRAK

Memahami keplastikan fenotip intrakhusus adalah satu pra-syarat untuk mengenal pasti stok, kajian evolusi dan pemanfaatan lestari dan pemuliharaan dalam perikanan. Dalam kajian ini kepelbagaian fenotip intrakhusus dinilai dari segi ciri luaran (iaitu meristik, morfometri dan morfometri dasarkan truss) daripada populasi liar ikan nandus dari empat sumber air tawar di selatan-barat Bangladesh. Sampel ikan dikumpulkan dari Arial Kha River, Madaripur (AKRM), ( $n=26)$; Sungai Nabaganga, Jhenaidah (NRJ), $(n=22) ;$ Bohnni Baor, Gopalganj $(B B J)$, $(n=26)$; dan Dhakuria Beel, Jashore (DBJ), $(n=22)$. Data meristik, morfometri dan rangkaian truss dianalisis menggunakan varians satu arah (ANOVA) diikuti dengan ujian Post-hoc (Tukey-HSD). Perhitungan meristik untuk kesemua sampel menunjukkan perbezaan yang signifikan hanya dalam satu ciri daripada enam ciri manakala perbezaan yang signifikan diperhatikan dalam 8 ciri morfometrik dan 31 rangkaian data truss masing-masing daripada 16 ciri morfometrik dan 35 rangkaian data truss. Di samping itu, analisis komponen utama (PCA) dan analisis fungsi diskriminasi (CVA) dilakukan dengan menggunakan morfometrik dan data rangkaian berasaskan truss. Hasil daripada PCA dan CVA menunjukkan populasi terpisah sepenuhnya serta membentuk kelompok yang padat dalam tahap intrapopulasi. Tiga dendrogram secara bebas berdasarkan hubungan fenotip antara individu daripada empat populasi dibina. Populasi NRJ, BBG dan DBJ membentuk populasi kumpulan masing-masing berdasarkan meristik, morfometrik dan truss morfometrik. Maklumat asas yang dihasilkan daripada kajian semasa adalah mudah untuk kajian genetik dan pemuliharaan populasi Nandus secara in situ di Bangladesh.

Kata kunci: Air tawar; analisis fungsi diskriminasi; meristik; morfometrik; morfometri Truss; nandus 


\section{INTRODUCTION}

Phenotypic plasticity is the ability of an organism to adjust its body maintenance in response to genetic-environmental interactions. Sometimes, phenotypic plasticity, phenotypic responsiveness, flexibility, and condition sensitivity are entirely synonymous in evolutionary biology (WestEberhard 1989). The plethora of outcomes, such as changes in body shape and size, allometry, feeding habits, sexual dimorphism, and behavioral and physiological states, can be collectively or solely achieved from phenotypic plasticity after a certain period of time (Langerhans 2008). Thus, similar to other organisms with this property, fishes are not an exception. Fishes also exhibit an outstanding extent of variation in their external body shape morphologies, such as meristic and morphometric characters, at a species level (Oufiero \& Whitlow 2016). Consequently, morphometrics can be defined as an array of quantitative analyses, such as biological outline, or shape disparity among organisms with respect to environmental factors (Webster \& Sheets 2010). Moreover, studies on the morphogenesis of fishes plays a fundamental role in evolutionary analysis and proper management (Başusta et al. 2014; Kalhoro et al. 2015).

Information related to the stock structure analysis of a species or a population is a prerequisite of the expansion of proper biodiversity management and conservation (Turan et al. 2005). Morphological dissimilarities are observable characteristics in a fish or a fish population and caused by genetic factors, genetic-environmental interactions, and abiotic and biotic influences (Crispo 2008; Silva et al. 2013). Generally, in early developmental stages, fishes express their phenotypic plasticity in two ways, that is, isometric size variation due to growth and allometric shape variation caused by developmental alteration (Cadrin 2000). Freshwater fishes exhibit a high degree of body shape variation because of physiological and environmental conditions, resulting in genetic variation and phenotypic plasticity (Eklöv \& Svanbäck 2005). Numerous techniques, such as morphometrics and meristics, traditional tags, otolith microchemistry, and electronic tags, have been extensively used for stock identification. Morphometric traits are one of the most used and cost-effective methods to detect intraspecific phenotypic variation in species (Mir et al. 2013). Naturally, fishes undergo ontogeny in an allometric pattern from the beginning of their life cycle (Hood \& Heins 2000; Svanbäck \& Eklöv 2002). To reinforce the inherent limitation of conventional morphometric approaches, the truss-networks formed by two or more interconnecting distances acrossbody that ultimately produced chronological sequence of associated polygons has been progressively utilized (Strauss \& Bookstein 1982).
Nandus is a freshwater fish commonly known as mud perch or mottled nandus and considered a small indigenous species in Bangladesh (Ross et al. 2003). This fish species is widely distributed in fresh and brackish waters, including ditches, ponds, beels (saucer-shaped perennial water bodies), and inundated fields throughout South Asian countries (Ahmed 2008; Rahman 2005). Nandus is a carnivorous organism that entirely feeds on larvae and insects, crustaceans, filamentous algae, and small fishes (Agarwal \& Sharma 1966). Although this species is considered a bony fish that survives at a low oxygen level, it can camouflage when any prey, small fish, and even a predator is present in a water body (Mustafa et al. 1980). This fish also plays a substantial role in the overall nutrition for poor-rural-living and low-incomegenerating communities in Bangladesh (Das \& Zamal 2000). According to IUCN-Bangladesh (Chowdhury 2015), this species is categorized as nearly threatened because of habitat destruction, overexploitation, anthropogenic activities, and climate change (Rahman 2005). As such, morphometric and meristic studies should be conducted to detect intraspecific phenotypic plasticity and ensure sustainability in the future.

At present, no adequate information regarding the intraspecific phenotypic variation in $N$. nandus in the freshwaters of Bangladesh is available. Therefore, this study aimed to investigate the intraspecific phenotypic variations in $N$. nandus based on meristic, morphometric, and truss network system.

\section{MATERIALS AND METHODS}

\section{FISH SAMPLING}

A total of 100 individuals of Nandus sp. were collected from four different freshwater sources in Bangladesh from September 2017 to November 2017: Arial Kha River, Madaripur (AKRM); Nabaganga River, Jhenaidah (NRJ); Bohnni Baor, Gopalganj (BBG); and Dhakuria Beel, Jashore (DBJ) (Figure 1 \& Table 1). The samples were placed in an ice box and immediately brought into the Laboratory of Fish Biology and Aquaculture, Jashore University of Science and Technology, Bangladesh. The minimum and maximum total lengths (TL) of the fish specimens were 6.94 and $12.89 \mathrm{~cm}$, respectively.

\section{COUNTING OF MERISTIC CHARACTERS}

In six meristic characters, the numbers of dorsal spiny fin rays (DSFR), dorsal soft fin rays (SFR), caudal fin rays (CFR), anal fin rays (AFR), pelvic fin rays (PevFR), and pectoral fin rays (PecFR) were counted in each sample by using magnifying glasses and needles. 


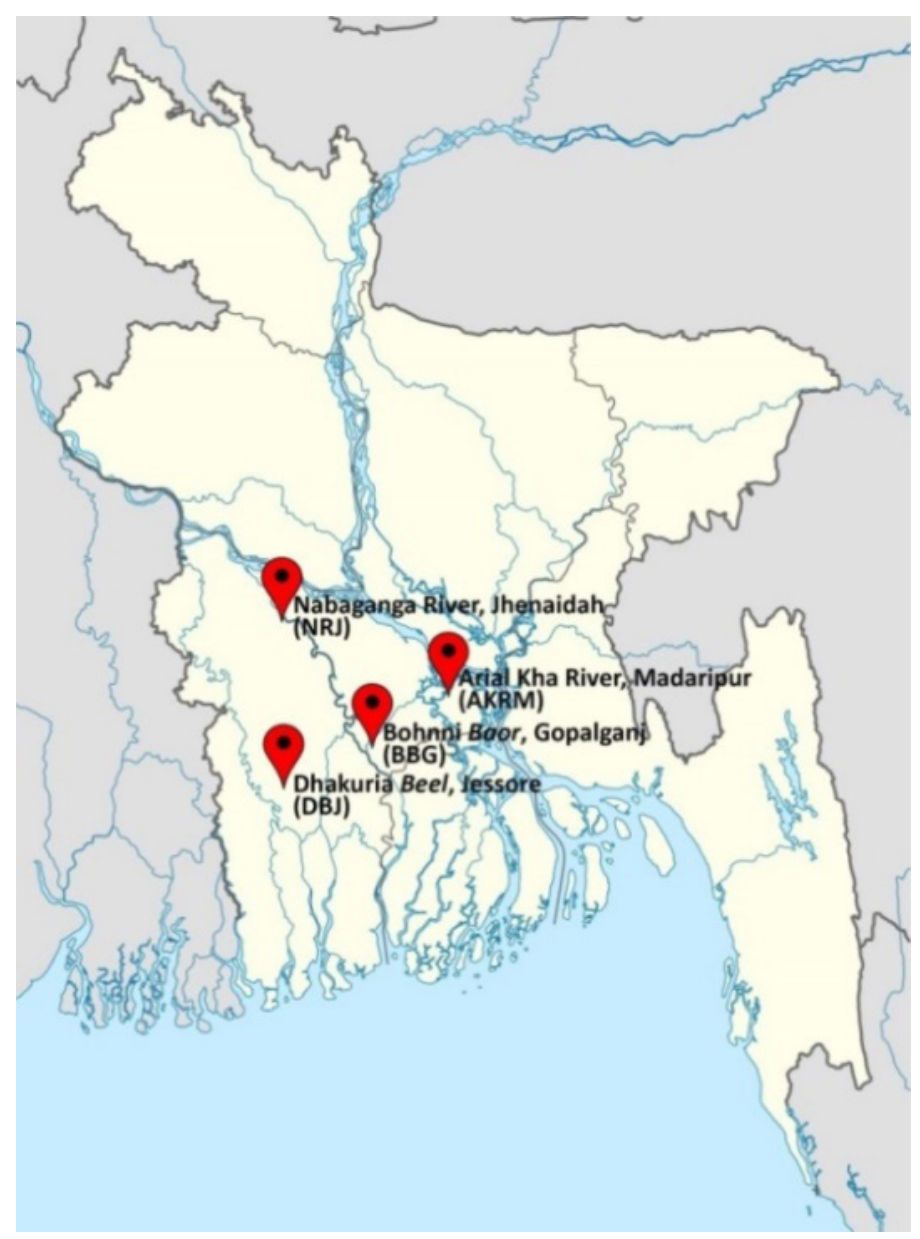

FIGURE 1. Map of Bangladesh showing collection sites of N. nandus from four freshwater sources

TABLE 1. Sampling details of N. nandus from four freshwater sources in Bangladesh

\begin{tabular}{lccccc}
\hline Serial no. & Populations & Abbreviations & Locations & $\begin{array}{c}\text { Number of } \\
\text { specimens }\end{array}$ & $\begin{array}{c}\text { Mean SL in } \\
\text { cm (SD) }\end{array}$ \\
\hline 1 & Arial Kha River, Madaripur & AKRM & $23.23^{\circ} \mathrm{N} 90.18^{\circ} \mathrm{E}$ & 26 & $9.55(0.54)$ \\
2 & Nabaganga River, Jhenaidah & NRJ & $23.54^{\circ} \mathrm{N} 89.17^{\circ} \mathrm{E}$ & 22 & $7.76(0.91)$ \\
3 & Bohnni Baor, Gopalganj & BBG & $23.16^{\circ} \mathrm{N} 89.21^{\circ} \mathrm{E}$ & 26 & $7.38(1.26)$ \\
4 & Dhakuria Beel, Jashore & DBJ & $23.16^{\circ} \mathrm{N} 89.21^{\circ} \mathrm{E}$ & 26 & $8.42(1.19)$ \\
\hline
\end{tabular}

\section{MEASUREMENT OF MORPHOMETRIC AND TRUSS} NETWORKS

First, the image of the samples was digitized after the fish were thawed under running tap water, wiped well, and placed on a smooth platform with a white paper as a background. Then, the individual fish was categorized with a definite code for documentation. A Cybershot DSC-W730 digital camera (Sony, China) was used to capture digital images, which provided a whole record of body shape and allowed re-measurements when necessary 
(Cadrin \& Friedland 1999). The morphometrics and truss distances from the digital images of the specimens were extracted using tpsDig2V2.1 (Rohlf 2006; Table 2). In the case of truss network distances, 13 landmarks were created on each fish image, which was constructed by interconnecting 35 truss network measurements (Figure 2).

TABLE 2. Seventeen morphometric characters were used for the analysis intra/specific phenotypes of mottled N. nandus

\begin{tabular}{|c|c|}
\hline Characters & Description \\
\hline Total length (TL) & Distance from the tip of the lower jaw to the longest caudal fin ray \\
\hline Standard length (SL) & Distance from the tip of the lower jaw to the end of the vertebral column \\
\hline Pre-dorsal length (PDL) & Front of the lower lip to the origin of the first ray of the first dorsal fin \\
\hline Post orbital head length (POL) & Distance from the posterior margin of the eye to the end of the operculum \\
\hline Pre-pectoral length (PPCL) & Front of the lower lip to the origin of the pectoral fin \\
\hline Pre-pelvic length (PPVL) & Front of the lower lip to the origin of thwwe pelvic fin \\
\hline Length of the first dorsal fin base (LDFB1) & From base of first dorsal fin ray to base of last dorsal fin ray \\
\hline Length of the second dorsal fin base (LDFB2) & From base of the second dorsal fin ray to base of last dorsal fin ray \\
\hline Length of anal fin base (LAFB) & From base of the first anal fin ray to base of the last anal fin ray \\
\hline Upper jaw length (UJL) & Straight line measurement between the snout tip and posterior edge of maxilla \\
\hline Lower jaw length (LJL) & $\begin{array}{l}\text { Straight line measurement between the snout tip and posterior edge of } \\
\text { mandible }\end{array}$ \\
\hline Body depth (BD) & Maximum depth measured from the base of the first dorsal fin ray \\
\hline Snout length (SNL) & The front of the upper lip to the fleshy anterior edge of the orbit \\
\hline Eye diameter (ED) & The greatest crystal-like diameter of the orbit \\
\hline Head length (HD) & $\begin{array}{l}\text { Distance between front of the lower lip to the posterior end of the opercular } \\
\text { membrane }\end{array}$ \\
\hline Depth of caudal peduncle (DCP) & The least depth of the tail base \\
\hline Inter orbital (IO) & Distance between dorsal side of both eyes \\
\hline
\end{tabular}

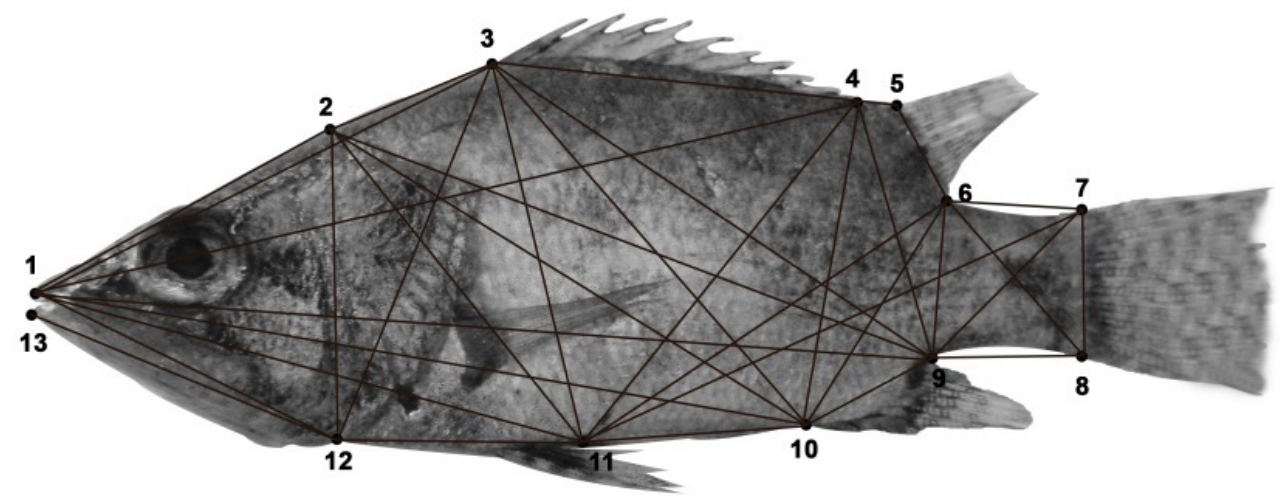

FIGURE 2. Location of 13 anatomic landmarks of $N$. nandus for constructing 35 truss networks on fish body illustrated as close circle (black). The descriptions of landmarks are follows: (1) anterior tip of the upper snout, (2) forehead (end of the frontal bone), (3) origin of the first dorsal fin, (4) endpoint of the first dorsal fin, (5) origin of the second dorsal fin, (6) endpoint of the second dorsal fin, (7) dorsal origin of caudal fin, (8) ventral origin of the caudal fin, (9) endpoint of the anal fin, (10) origin of anal fin, (11) endpoint of the pelvic fin, (12) down of the operculum, and (13) anterior tip of the lower snout 


\section{DATA ANALYSES}

All original morphometric and truss data were subjected to general descriptive analysis to check their normality before they were further examined using SPSS version 21 (SPSS, Chicago, IL, USA). An allometric formula, which was described by Elliott et al. (1995) and slightly modified in the present study, was used to remove the size effect from the dataset based on (1):

$$
\mathrm{M}_{\mathrm{adj}}=\mathrm{M}\left(\mathrm{L}_{\mathrm{s}} / \mathrm{L}_{\mathrm{o}}\right)^{\mathrm{b}}
$$

where $M$ is the original measurement; $M_{\text {adj }}$ is the sizeadjusted measurement; $\mathrm{L}_{\mathrm{o}}$ is the TL of the fish; $\mathrm{L}_{\mathrm{s}}$ is the overall mean of the TL of all the fish from all the samples; and $b$ is estimated as the slope of the regression of $\log M$ on $\log \mathrm{L}_{\mathrm{o}}$ by using all the fish samples in all the populations for each character from the observed data. Meristic, morphometric, and truss distance data were compared among populations via one-way ANOVA followed by post hoc (Tukey-HSD) test. Size-adjusted data were also subjected to principal component analysis (PCA) and discriminant function analysis (canonical variate analyses (CVA)). All statistically analyzed data were considered using a probability of $\mathrm{P}=0.05$. Three separate dendrograms with a complete linkage and a Euclidean distance were drawn using meristic, morphometric, and truss morphometric data. The entire statistical analyses were performed using SPSS version 21 (SPSS, Chicago, IL, USA) and R version 3.5.2.

\section{RESULTS}

Mean values were compared through one-way ANOVA followed by Tukey-HSD post hoc test of each meristic, morphometric, and truss morphometric character from four wild Nandus populations (Tables 3 to 5, respectively). In meristic characters, PecFR $(F=7.182, \mathrm{P}<0.05)$ of the $\mathrm{BBG}$ and DBJ populations were similar and NRJ population significantly differed from BBG and DBJ populations, while AKRM population was intermediate. The differences $(\mathrm{P}>0.05)$ in DSFR $(\mathrm{F}=1.558, \mathrm{P}>0.05)$, SFR $(\mathrm{F}=2.335$, $\mathrm{P}>0.05), \mathrm{CFR}(\mathrm{F}=0.765, \mathrm{P}>0.05), \operatorname{AFR}(\mathrm{F}=1.058, \mathrm{P}$ $>0.05)$, and PevFR $(\mathrm{F}=1.058, \mathrm{P}>0.05)$ among the four populations were not statistically significant (Table 3 ).

Eight morphometric characters (i.e., SL, PDL, PPVL, LDFB1, LAFB, UJL, BD, and HL) also significantly varied $(\mathrm{P}<0.05)$ among 16 morphometric characters (Table 4). For instance, SL $(F=2.898, P<0.05)$ of the AKRM and DBJ populations were highly significant to each other, whereas the BBG and NRJ populations were intermediate among the four populations. In case of PDL $(\mathrm{F}=3.870, \mathrm{P}<0.05)$, the AKRM and BBG populations resembled similar and showed significant difference from DBJ population, conversely NRJ population was intermediate among the four populations. Similarly, for PPVL $(F=6.740, \mathrm{P}<0.05)$, DBJ population showed significant disparity compared to the three remaining populations of AKRM, BBG, and NRJ. Additionally, LDFB1 $(\mathrm{F}=3.700, \mathrm{P}<0.05)$ character showed significant disparity between BBG and DBJ populations, whilst AKRM and NRJ populations exhibited intermediate among the four populations. Moreover, LAFB ( $\mathrm{F}=5.868, \mathrm{P}<$ 0.05 ) character of AKRM population possessed significant difference from BBG and DBJ populations while NRJ population exhibited as intermediate. The UJL $(F=6.220$, $\mathrm{P}<0.05$ ) character of BBG and NRJ populations showed significant differences to each other, but AKRM and DBJ populations remained intermediate and equally similar to each other. Furthermore, the $\mathrm{BD}(\mathrm{F}=4.116, \mathrm{P}<0.05)$ and HL $(F=20.299, P<0.05)$ characters showed significant differences in AKRM, BBG, and DBJ populations to each other even though the NRJ population showed intermediate.

TABLE 3. Comparison of the (mean $\pm \mathrm{SD}$ ) of meristic characters of $N$. nandus in four populations namely, Arial Kha river, Madaripur (AKRM); Bohnni baor, Gopalganj (BBG); Nabaganga river, Jhenidah (NRJ) and Dhakuria beel, Jashore (DBJ) in Bangladesh

\begin{tabular}{lcccccc}
\hline \multicolumn{1}{c}{ Meristic characters } & AKRM & BBG & NRJ & DBJ & F & P-value \\
\hline DSFR & $12.15 \pm 1.12$ & $12.44 \pm 0.72$ & $12.73 \pm 0.72$ & $12.48 \pm 0.96$ & 1.558 & 0.205 \\
SFR & $11.53 \pm 1.10$ & $10.72 \pm 1.31$ & $11.41 \pm 1.00$ & $11.40 \pm 1.35$ & 2.355 & 0.077 \\
CFR & $13.23 \pm 0.71$ & $13.28 \pm 0.89$ & $13.36 \pm 1.04$ & $13.60 \pm 1.08$ & 0.768 & 0.515 \\
AFR & $10.15 \pm 1.43$ & $9.68 \pm 0.90$ & $9.73 \pm 1.42$ & $10.16 \pm 1.25$ & 1.058 & 0.371 \\
PevFR & $6.62 \pm 1.03$ & $6.28 \pm 0.89$ & $7.23 \pm 1.99$ & $6.64 \pm 0.95$ & 2.230 & 0.090 \\
PecFR & $12.31 \pm 1.15^{\mathrm{ab}}$ & $11.36 \pm 2.03^{\mathrm{b}}$ & $13.13 \pm 1.08^{\mathrm{a}}$ & $11.48 \pm 1.44^{\mathrm{b}}$ & 7.182 & $0.000^{*}$ \\
\hline
\end{tabular}

$* \mathrm{P}<0.05$. SD: Standard deviation. F: The ratio of between-group variability and within group variability in one-way analysis of variance (ANOVA). Different small superscripts in each row differs the values of meristic characters 
TABLE 4. Comparison of the (mean $\pm \mathrm{SD}$ ) of morphometric characters of $N$. nandus in four populations namely, Arial Kha river, Madaripur (AKRM); Bohnni baor, Gopalganj (BBG); Nabaganga river, Jhenidah (NRJ) and Dhakuria beel, Jashore (DBJ) in Bangladesh

\begin{tabular}{|c|c|c|c|c|c|c|}
\hline Morphometric characters & AKRM & BBG & NRJ & DBJ & $\mathrm{F}$ & P-value \\
\hline SL & $8.19 \pm 0.37^{\mathrm{b}}$ & $8.31 \pm 0.41^{\mathrm{ab}}$ & $8.23 \pm 0.23^{\mathrm{ab}}$ & $8.44 \pm 0.27^{\mathrm{a}}$ & 2.898 & $0.039^{*}$ \\
\hline PDL & $4.03 \pm 0.27^{\mathrm{a}}$ & $3.77 \pm 0.21^{\mathrm{a}}$ & $3.88 \pm 0.37^{\mathrm{ab}}$ & $3.68 \pm 0.61^{\mathrm{b}}$ & 3.870 & $0.012^{*}$ \\
\hline POL & $2.21 \pm 0.63$ & $2.45 \pm 0.71$ & $2.26 \pm 0.57$ & $2.56 \pm 0.61$ & 1.686 & 0.175 \\
\hline PPCL & $3.32 \pm 0.33$ & $3.20 \pm 0.25$ & $3.34 \pm 0.29$ & $3.33 \pm 0.34$ & 1.178 & 0.322 \\
\hline PPVL & $2.86 \pm 0.28^{\mathrm{b}}$ & $2.71 \pm 0.48^{\mathrm{b}}$ & $2.75 \pm 0.39^{b}$ & $3.18 \pm 0.48^{\mathrm{a}}$ & 6.740 & $0.000^{*}$ \\
\hline LDFB1 & $3.08 \pm 0.34^{\mathrm{ab}}$ & $2.88 \pm 0.30^{\mathrm{b}}$ & $3.07 \pm 0.32^{\mathrm{ab}}$ & $3.25 \pm 0.57^{\mathrm{a}}$ & 3.700 & $0.014^{*}$ \\
\hline LDFB2 & $0.72 \pm 0.13$ & $0.75 \pm 0.16$ & $0.77 \pm 0.20$ & $0.82 \pm 0.17$ & 0.166 & 0.919 \\
\hline LAFB & $1.14 \pm 0.11^{\mathrm{a}}$ & $0.97 \pm 0.18^{\mathrm{b}}$ & $1.04 \pm 0.22^{\mathrm{ab}}$ & $0.94 \pm 0.20^{\mathrm{b}}$ & 5.868 & $0.001^{*}$ \\
\hline UJL & $0.88 \pm 0.23^{\mathrm{bc}}$ & $0.82 \pm 0.16^{\mathrm{c}}$ & $1.15 \pm 0.51^{\mathrm{a}}$ & $1.13 \pm 0.37^{\mathrm{ab}}$ & 6.220 & $0.001^{*}$ \\
\hline LJL & $0.85 \pm 0.23$ & $0.96 \pm 0.26$ & $1.01 \pm 0.40$ & $1.29 \pm 0.56$ & 1.546 & 0.208 \\
\hline $\mathrm{BD}$ & $3.02 \pm 0.15^{\mathrm{a}}$ & $2.69 \pm 0.21^{\mathrm{b}}$ & $2.78 \pm 0.42^{\mathrm{ab}}$ & $2.64 \pm 0.67^{\mathrm{b}}$ & 4.116 & $0.009^{*}$ \\
\hline SNL & $0.73 \pm 0.16$ & $0.64 \pm 0.13$ & $0.82 \pm 0.49$ & $0.68 \pm 0.08$ & 1.803 & 0.152 \\
\hline ED & $0.69 \pm 0.10$ & $0.68 \pm 0.24$ & $0.66 \pm 0.11$ & $0.72 \pm 0.13$ & 0.688 & 0.588 \\
\hline $\mathrm{HL}$ & $2.45 \pm 0.45^{\mathrm{b}}$ & $1.77 \pm 0.73^{\mathrm{c}}$ & $2.94 \pm 0.85^{\mathrm{ab}}$ & $3.13 \pm 0.65^{\mathrm{a}}$ & 20.299 & $0.000^{*}$ \\
\hline DCP & $0.99 \pm 0.09$ & $1.06 \pm 0.33$ & $1.03 \pm 0.08$ & $1.08 \pm 0.10$ & 0.966 & 0.412 \\
\hline IO & $1.16 \pm 0.04$ & $1.17 \pm 0.03$ & $1.19 \pm 0.18$ & $1.20 \pm 0.09$ & 0.671 & 0.572 \\
\hline
\end{tabular}

$* \mathrm{P}<0.05$. SD: Standard deviation. F: The ratio of between-group variability and within group variability in one-way analysis of variance (ANOVA). Different small superscripts in each row differs the values of morphometric characters

In truss morphometric characters, out of 35 morphometric characters 31 showed significant differences (Table 5). The characters 2-3 ( $\mathrm{F}=38.546, \mathrm{P}<0.05), 4-5$ $(\mathrm{F}=18.408, \mathrm{P}<0.05), 7-8(\mathrm{~F}=20.082, \mathrm{P}<0.05), 8-9(\mathrm{~F}$ $=12.050, \mathrm{P}<0.05), 9-10(\mathrm{~F}=20.139, \mathrm{P}<0.05), 11-12$ $(\mathrm{F}=16.641, \mathrm{P}<0.05), 1-11(\mathrm{~F}=8.416, \mathrm{P}<0.05), 2-12$ $(\mathrm{F}=7.675, \mathrm{P}<0.05), 3-12(\mathrm{~F}=28.377, \mathrm{P}<0.05), 3-11$ $(\mathrm{F}=14.315, \mathrm{P}<0.05), 3-10(\mathrm{~F}=13.878, \mathrm{P}<0.05), 4-11$ $(\mathrm{F}=7.415, \mathrm{P}<0.05), 6-9(\mathrm{~F}=3.614, \mathrm{P}<0.05), 2-9(\mathrm{~F}=$ $11.030, \mathrm{P}<0.05)$, and $1-9(\mathrm{~F}=31.212, \mathrm{P}<0.05)$ of the DBJ population demonstrated highly significant differences from those of the three remaining populations. In addition, $10-11(\mathrm{~F}=8.567, \mathrm{P}<0.05)$ and $1-3(\mathrm{~F}=9.874, \mathrm{P}<0.05)$ characters of DBJ population significantly differed from the three remaining populations. Similarly, 5-6 (F = 13.271, $\mathrm{P}<0.05)$ character showed significant difference in NRJ population from the three remaining populations of AKRM, BBG, and DBJ.

On the flip of site, 3-4 $(\mathrm{F}=9.915, \mathrm{P}<0.05)$ character demonstrated significant differences in BBG and DBJ populations whereas AKRM and NRJ populations remained intermediate among the four populations. Similarly, 6-7 (F $=5.046, \mathrm{P}<0.05)$ character showed significant difference in NRJ population than the BBG and DBJ populations while AKRM population remained intermediate among the three remaining populations. Additionally, 2-11 (F =
4.413, $\mathrm{P}<0.05)$ character proved significant differences in BBG and DBJ populations than the NRJ population whereas AKRM population showed intermediate among the three remaining populations. Likewise, 2-10 ( $\mathrm{F}=$ $6.829, \mathrm{P}<0.05)$ character showed significant difference in AKRM and DBJ populations whilst BBG and NRJ populations showed intermediate among the three remaining populations. Correspondingly, 3-9 $(\mathrm{F}=18.693$, $\mathrm{P}<0.05)$ character demonstrated significant difference in DBJ population than the NRJ and BBG populations but the AKRM population exhibited intermediate between BBG and NRJ populations. Together with, 4-10 (F = $7.107, \mathrm{P}<0.05)$ character proved significant difference in BBG population than NRJ population while AKRM and DBJ populations remained intermediate between $\mathrm{BBG}$ and NRJ populations. Additionally, 6-11 ( $\mathrm{F}=4.641, \mathrm{P}<$ $0.05)$ character demonstrated significant difference in AKRM and DBJ populations but BBG and NRJ populations showed intermediate among the four populations. Equally, 1-10 ( $\mathrm{F}=53.819, \mathrm{P}<0.05)$ character showed significant differences in DBJ, AKRM and BBG populations whilst NRJ population remained intermediate state among the populations. Furthermore, 7-11 ( F = 13.271, $\mathrm{P}<$ 0.05 ) character of DBJ population showed significant deviation than the BBG population while AKRM and NRJ populations showed intermediate among the populations. 
TABLE 5. Comparison of the (mean $\pm \mathrm{SD}$ ) of truss morphometric characters of $N$. nandus in four populations namely, Arial Kha river, Madaripur (AKRM); Bohnni baor, Gopalganj (BBG); Nabaganga river, Jhenidah (NRJ) and Dhakuria beel, Jashore (DBJ) in Bangladesh

\begin{tabular}{|c|c|c|c|c|c|c|}
\hline Characters & AKRM & BBG & NRJ & DBJ & $\mathrm{F}$ & P-value \\
\hline $1-2$ & $2.98 \pm 0.33$ & $3.08 \pm 0.65$ & $2.96 \pm 0.71$ & $3.26 \pm 0.41$ & 1.572 & 0.201 \\
\hline $2-3$ & $1.00 \pm 0.38^{b}$ & $0.87 \pm 0.19^{b}$ & $0.99 \pm 0.17^{b}$ & $2.32 \pm 1.00^{\mathrm{a}}$ & 38.546 & $0.000^{*}$ \\
\hline $3-4$ & $2.56 \pm 0.42^{\mathrm{bc}}$ & $2.20 \pm 1.00^{\mathrm{c}}$ & $2.87 \pm 0.54^{\mathrm{ab}}$ & $3.34 \pm 0.95^{\mathrm{a}}$ & 9.915 & $0.000^{*}$ \\
\hline $4-5$ & $0.51 \pm 0.21^{\mathrm{b}}$ & $0.50 \pm 0.17^{b}$ & $0.56 \pm 0.46^{\mathrm{b}}$ & $1.97 \pm 1.50^{\mathrm{a}}$ & 18.408 & $0.000^{*}$ \\
\hline $5-6$ & $0.59 \pm 0.16^{\mathrm{b}}$ & $0.55 \pm 0.11^{\mathrm{b}}$ & $0.78 \pm 0.28^{\mathrm{a}}$ & $0.45 \pm 0.14^{\mathrm{b}}$ & 13.271 & $0.000^{*}$ \\
\hline $6-7$ & $0.88 \pm 0.08^{\mathrm{ab}}$ & $0.79 \pm 0.13^{b}$ & $0.93 \pm 0.14^{\mathrm{a}}$ & $0.79 \pm 0.21^{\mathrm{b}}$ & 5.046 & $0.003^{*}$ \\
\hline $7-8$ & $0.95 \pm 0.06^{\mathrm{b}}$ & $1.01 \pm 0.14^{\mathrm{b}}$ & $1.01 \pm 0.14^{\mathrm{b}}$ & $1.23 \pm 0.17^{\mathrm{a}}$ & 20.082 & $0.000^{*}$ \\
\hline $8-9$ & $0.93 \pm 0.24^{b}$ & $0.87 \pm 0.09^{b}$ & $1.05 \pm 0.21^{\mathrm{b}}$ & $1.26 \pm 0.37^{\mathrm{a}}$ & 12.050 & $0.000^{*}$ \\
\hline $9-10$ & $1.29 \pm 0.57^{b}$ & $1.04 \pm 0.36^{\mathrm{b}}$ & $1.03 \pm 0.31^{\mathrm{b}}$ & $2.18 \pm 0.94^{\mathrm{a}}$ & 20.139 & $0.000^{*}$ \\
\hline $10-11$ & $2.18 \pm 0.51^{\mathrm{a}}$ & $2.38 \pm 0.54^{\mathrm{a}}$ & $2.23 \pm 0.59^{\mathrm{a}}$ & $1.69 \pm 0.39^{b}$ & 8.567 & $0.000^{*}$ \\
\hline $11-12$ & $1.71 \pm 0.51^{\mathrm{b}}$ & $1.54 \pm 0.22^{\mathrm{b}}$ & $1.63 \pm 0.38^{b}$ & $2.38 \pm 0.67^{\mathrm{a}}$ & 16.641 & $0.000^{*}$ \\
\hline $12-1$ & $2.13 \pm 0.32$ & $2.09 \pm 0.18$ & $1.96 \pm 0.27$ & $1.95 \pm 0.62$ & 1.364 & 0.264 \\
\hline $12-13$ & $2.46 \pm 0.88^{\mathrm{a}}$ & $2.18 \pm 0.65^{\mathrm{ab}}$ & $1.67 \pm 0.74^{b}$ & $2.79 \pm 1.06^{\mathrm{a}}$ & 7.288 & $0.000^{*}$ \\
\hline $1-3$ & $3.84 \pm 0.62^{\mathrm{a}}$ & $3.84 \pm 0.33^{\mathrm{a}}$ & $3.90 \pm 0.61^{\mathrm{a}}$ & $3.14 \pm 0.71^{\mathrm{b}}$ & 9.874 & $0.000^{*}$ \\
\hline $1-11$ & $3.61 \pm 0.69^{b}$ & $3.34 \pm 0.42^{\mathrm{b}}$ & $3.36 \pm 0.51^{b}$ & $4.08 \pm 0.70^{\mathrm{a}}$ & 8.416 & $0.000^{*}$ \\
\hline $2-12$ & $2.89 \pm 0.22^{b}$ & $2.98 \pm 0.57^{b}$ & $2.83 \pm 0.45^{\mathrm{b}}$ & $3.42 \pm 0.58^{\mathrm{a}}$ & 7.675 & $0.000^{*}$ \\
\hline $2-11$ & $3.07 \pm 0.45^{\mathrm{ab}}$ & $3.33 \pm 0.79^{\mathrm{a}}$ & $2.87 \pm 0.41^{b}$ & $3.41 \pm 0.54^{\mathrm{a}}$ & 4.413 & $0.006^{*}$ \\
\hline $2-10$ & $4.19 \pm 0.63^{\mathrm{a}}$ & $3.75 \pm 0.30^{\mathrm{bc}}$ & $4.18 \pm 0.60^{\mathrm{ab}}$ & $3.59 \pm 0.70^{c}$ & 6.829 & $0.000^{*}$ \\
\hline $3-12$ & $3.36 \pm 0.35^{\mathrm{b}}$ & $3.08 \pm 0.24^{\mathrm{b}}$ & $3.23 \pm 0.34^{\mathrm{b}}$ & $4.03 \pm 0.57^{\mathrm{a}}$ & 28.377 & $0.000^{*}$ \\
\hline $3-11$ & $3.00 \pm 0.23^{b}$ & $3.10 \pm 0.57^{b}$ & $3.12 \pm 0.63^{b}$ & $3.81 \pm 0.50^{\mathrm{a}}$ & 14.315 & $0.000^{*}$ \\
\hline $3-10$ & $3.80 \pm 0.18^{b}$ & $3.60 \pm 0.33^{\mathrm{b}}$ & $3.65 \pm 0.65^{\mathrm{b}}$ & $4.27 \pm 0.41^{\mathrm{a}}$ & 13.878 & $0.000^{*}$ \\
\hline $3-9$ & $3.92 \pm 0.24^{\mathrm{bc}}$ & $3.56 \pm 0.33^{c}$ & $4.14 \pm 0.47^{b}$ & $4.60 \pm 0.81^{\mathrm{a}}$ & 18.693 & $0.000^{*}$ \\
\hline $4-11$ & $3.78 \pm 0.59^{\mathrm{b}}$ & $3.58 \pm 0.48^{\mathrm{b}}$ & $3.55 \pm 0.64^{\mathrm{b}}$ & $4.34 \pm 0.91^{\mathrm{a}}$ & 7.415 & $0.000^{*}$ \\
\hline $4-10$ & $2.56 \pm 0.41^{b c}$ & $3.28 \pm 0.89^{\mathrm{a}}$ & $2.54 \pm 0.68^{c}$ & $3.07 \pm 0.71^{\mathrm{ab}}$ & 7.107 & $0.000^{*}$ \\
\hline $4-9$ & $2.39 \pm 0.69^{b}$ & $1.60 \pm 0.29^{\mathrm{a}}$ & $2.04 \pm 0.47^{b}$ & $2.37 \pm 0.53^{b}$ & 13.511 & $0.000^{*}$ \\
\hline $6-9$ & $1.40 \pm 0.37^{b}$ & $1.39 \pm 0.17^{\mathrm{b}}$ & $1.50 \pm 0.36^{\mathrm{b}}$ & $1.64 \pm 0.32^{\mathrm{a}}$ & 3.614 & $0.016^{*}$ \\
\hline $6-8$ & $1.39 \pm 0.11$ & $1.46 \pm 0.18$ & $1.46 \pm 0.18$ & $2.10 \pm 0.54$ & 1.388 & 0.251 \\
\hline $7-9$ & $1.47 \pm 0.13^{b}$ & $2.24 \pm 1.40^{\mathrm{a}}$ & $1.71 \pm 0.71^{\mathrm{ab}}$ & $1.83 \pm 0.78^{\mathrm{ab}}$ & 3.410 & $0.021^{*}$ \\
\hline $6-11$ & $3.99 \pm 0.33^{\mathrm{a}}$ & $3.41 \pm 0.63^{\mathrm{ab}}$ & $3.62 \pm 1.15^{\mathrm{ab}}$ & $2.96 \pm 1.51^{\mathrm{b}}$ & 4.641 & $0.004^{*}$ \\
\hline $6-10$ & $2.23 \pm 0.27$ & $2.38 \pm 1.15$ & $2.30 \pm 0.79$ & $2.13 \pm 1.16$ & 0.371 & 0.774 \\
\hline $2-9$ & $4.83 \pm 0.89^{b}$ & $4.76 \pm 0.92^{b}$ & $4.35 \pm 0.93^{b}$ & $5.95 \pm 1.30^{\mathrm{a}}$ & 11.030 & $0.000^{*}$ \\
\hline $1-4$ & $6.36 \pm 0.78^{b}$ & $5.11 \pm 0.72^{\mathrm{c}}$ & $6.01 \pm 0.91^{\mathrm{b}}$ & $7.83 \pm 1.27^{\mathrm{a}}$ & 36.578 & $0.000^{*}$ \\
\hline $1-10$ & $6.13 \pm 0.34^{b}$ & $5.31 \pm 0.67^{\mathrm{c}}$ & $5.86 \pm 1.00^{\mathrm{ab}}$ & $7.98 \pm 1.03^{\mathrm{a}}$ & 53.819 & $0.000^{*}$ \\
\hline $1-9$ & $6.99 \pm 0.47^{b}$ & $5.92 \pm 0.82^{\mathrm{c}}$ & $6.78 \pm 0.78^{b}$ & $8.22 \pm 1.21^{\mathrm{a}}$ & 31.212 & $0.000^{*}$ \\
\hline $7-11$ & $4.82 \pm 0.35^{\mathrm{ab}}$ & $4.61 \pm 0.57^{b}$ & $4.74 \pm 0.52^{\mathrm{ab}}$ & $5.14 \pm 0.72^{\mathrm{a}}$ & 4.233 & $0.007^{*}$ \\
\hline
\end{tabular}

* $\mathrm{P}<0.05$. SD: Standard deviation. F: The ratio of between-group variability and within group variability in one-way analysis of variance (ANOVA). Different small superscripts in each row differs the values of truss morphometric characters 
Multivariate analyses (i.e. PCA and CVA) were performed using meristic, morphometric, and truss morphometric data to detect the exact causes of variation in the specimens of the four populations. However, the insufficient sample size is a major bottleneck of the fish morphology studies during multivariate analysis. In this case, a ratio of sample size $(\mathrm{N})$ among all specimens and the number of characters (F) of at least 2.8-3.5 was considered (Kocovsky et al. 2009; Parsons et al. 2003). Insignificant $\mathrm{N}$ values may fail to adequately capture covariance or morphological variation, possibly leading to false conclusions regarding changes among populations (McGarigal et al. 2000). However, in the present study, the total number of specimens was $100(\mathrm{~N})$, and the numbers of meristic, morphometric, and truss morphometric characters were $6(\mathrm{P}), 16(\mathrm{P})$, and $35(\mathrm{P})$, respectively. Through the use of $\mathrm{N}$ and $\mathrm{P}$ values, the ultimate ratios were $16.66(\mathrm{~N}: \mathrm{P})$ for meristic parameters, $6.25(\mathrm{~N}: \mathrm{P})$ for morphometric parameters, and $2.85(\mathrm{~N}: \mathrm{P})$ for truss morphometric parameters, respectively. Consequently, PCA and CVA were performed to examine the characters (meristic, morphometric, and truss morphometrics) that mostly discriminated the populations. Before conducting the final PCA, data were validated with Bartlett's test of sphericity, and the Kaiser-Meyer-Olkin (KMO) measurement was performed. The statistical range of the KMO values varied between 0 and 1 . The KMO values were $0.526,0.577$, and 0.810 for meristic, morphometric, and truss morphometric characters, respectively, and Bartlett's test of sphericity showed significant results ( $\mathrm{P}$ $<0.05)$. According to Kaiser (1974), these KMO values can be ranked as moderate (0.5-0.7), good (0.7-0.8), and excellent (0.8-0.9). Therefore, the obtained results from $\mathrm{KMO}$ and Bartlett's tests suggested that the extracted data from each sample were highly fit for the factor analysis of meristic, morphometric, and truss morphometric characters.

In the PCA of six meristic characters, three factors with eigenvalues higher than 1 were extracted, and the remaining factors were discarded. The results elucidated $62.79 \%$ of the total variance. The first, second, and third principal components (PC1, PC2, and PC3, respectively) described $25.8,19.9$, and $17.1 \%$ of the variance, respectively (Table 6). Among the three PCs, the most significant loadings on PC1 were AFR, DSFR, SFR, CFR, and PecFR (Table 6). CVA produced three canonical variations (CV; i.e., CV1, CV2, and CV3) for six meristic characters. CV1, CV2, and CV3 accounted for 72.2, 18.6 , and $9.2 \%$ of group variability, respectively (Table 6). Pooled within-group correlations between canonical variables and CVs showed the following contributions of the six characters: PecFR to CV1, DSFR and SFR to CV2, and CFR and PevFR to CV3 (Table 6).

TABLE 6. Component loadings of first three principal components (PC) and canonical covariates (CV) for meristic characters in N. nandus collected from Arial Kha river, Madaripur (AKRM); Bohnni baor, Gopalganj (BBG); Nabaganga river, Jhenidah (NRJ) and Dhakuria beel, Jashore (DBJ) in Bangladesh. Character descriptions are given in material and methods section

\begin{tabular}{lcccccc}
\hline \multirow{2}{*}{ Meristic characters } & \multicolumn{3}{c}{ PCA } & \multicolumn{3}{c}{ CVA } \\
\cline { 2 - 6 } PecFR & PC 1 & PC 2 & PC 3 & CV 1 & CV 2 & CV 3 \\
DSFR & 0.415 & 0.561 & 0.439 & $0.742^{*}$ & -0.037 & -0.189 \\
SFR & 0.603 & 0.361 & -0.043 & 0.116 & $-0.583^{*}$ & 0.390 \\
AFR & 0.527 & -0.613 & -0.261 & 0.271 & $0.535^{*}$ & 0.524 \\
CFR & 0.686 & -0.347 & -0.023 & -0.024 & $0.500^{*}$ & 0.363 \\
PevFR & 0.468 & 0.383 & -0.362 & -0.049 & -0.061 & $0.663^{*}$ \\
Eigenvalue & 0.209 & -0.327 & 0.795 & 0.382 & -0.142 & $0.408^{*}$ \\
Variance \% & 1.546 & 1.195 & 1.026 & 0.412 & 0.106 & 0.530 \\
Cumulative \% & 25.8 & 19.9 & 17.1 & 72.2 & 18.6 & 9.2 \\
\hline * Largest absolute correlation between each variable and any canonical variate function & 62.8 & 72.2 & 90.8 & 100.0 \\
\hline
\end{tabular}


In the PCA of 16 morphometric characters, three factors with eigenvalues higher than 2 were extracted, and the remaining factors were discarded. These results elucidated $40.54 \%$ of the variance. $\mathrm{PC} 1, \mathrm{PC} 2$, and $\mathrm{PC} 3$ accounted for $17.7,13.4$, and $9.44 \%$ of the distinction, respectively. Among the three PCs, the most significant loadings on PC1 were HL, BD, PPCL, PPVL, UJL, LDFB1, and ED (Table 7). CVA produced three CVs (CV1, CV2, and CV3) for 16 morphometric characters; that is, CV1, $\mathrm{CV} 2$, and CV3 accounted for $64.9,25.5$, and $9.6 \%$ of group variability, respectively (Table 7). Pooled within-group correlations between canonical variables and CVs showed the following contributions among 16 morphometric characters: HL, LJL, and LDFB2 to CV1; LAFB, BD, PDL, SNL, SL, POL, PPCL, and DCP to CV2; and PPVL, UJL, LDFB1, ED, and IO to CV3 (Table 7).

TABLE 7. Component loadings of first three principal components (PC) and canonical covariates (CV) for morphometric characters in N. nandus collected from Arial Kha river, Madaripur (AKRM); Bohnni baor, Gopalganj (BBG); Nabaganga river, Jhenidah (NRJ) and Dhakuria beel, Jashore (DBJ) in Bangladesh. Character descriptions are given Table 2

\begin{tabular}{|c|c|c|c|c|c|c|}
\hline \multirow[b]{2}{*}{ Characters } & \multicolumn{3}{|c|}{ PCA } & \multicolumn{3}{|c|}{ CVA } \\
\hline & PC 1 & PC 2 & PC 3 & CV 1 & CV 2 & CV 3 \\
\hline HL & 0.598 & 0.010 & -0.391 & $0.598^{*}$ & 0.501 & 0.009 \\
\hline LJL & 0.225 & 0.464 & -0.515 & $0.173^{*}$ & -0.113 & -0.006 \\
\hline LDFB2 & 0.059 & 0.110 & 0.005 & $0.055^{*}$ & -0.041 & -0.022 \\
\hline LAFB & 0.337 & -0.644 & -0.078 & 0.188 & $0.069^{*}$ & 0.267 \\
\hline $\mathrm{BD}$ & 0.579 & -0.321 & 0.205 & -0.161 & $0.360^{*}$ & 0.326 \\
\hline PDL & 0.149 & -0.758 & 0.136 & -0.180 & $0.351^{*}$ & 0.207 \\
\hline SNL & 0.017 & -0.079 & -0.268 & 0.025 & $0.287^{*}$ & -0.227 \\
\hline SL & 0.326 & 0.361 & 0.511 & 0.188 & $-0.271^{*}$ & 0.085 \\
\hline POL & 0.146 & 0.380 & 0.544 & 0.109 & $-0.257^{*}$ & 0.026 \\
\hline PPCL & 0.724 & -0.389 & 0.025 & 0.101 & $0.202^{*}$ & 0.040 \\
\hline DCP & 0.164 & 0.288 & -0.070 & 0.085 & $-0.186^{*}$ & -0.083 \\
\hline PPVL & 0.668 & 0.293 & 0.151 & 0.329 & -0.053 & $0.533^{*}$ \\
\hline UJL & 0.458 & 0.380 & -0.443 & 0.331 & 0.191 & $-0.332^{*}$ \\
\hline LDFB1 & 0.654 & 0.026 & -0.097 & 0.251 & 0.147 & $0.281^{*}$ \\
\hline ED & 0.423 & 0.143 & 0.333 & 0.073 & -0.073 & $0.234^{*}$ \\
\hline IO & 0.060 & 0.242 & 0.235 & 0.112 & -0.009 & $-0.129^{*}$ \\
\hline Eigenvalue & 2.829 & 2.144 & 1.513 & 1.389 & 0.544 & 0.205 \\
\hline Variance $\%$ & 17.681 & 13.401 & 9.458 & 64.9 & 25.5 & 9.6 \\
\hline Cumulative $\%$ & 17.681 & 31.082 & 40.540 & 64.9 & 90.4 & 100.0 \\
\hline
\end{tabular}

* Largest absolute correlation between each variable and any discriminant function 
In the PCA of 35 truss morphometric characters, three factors with eigenvalues greater than 2 were extracted, and the remaining factors were discarded. The results elucidated $56.80 \%$ of the variance. $\mathrm{PC} 1, \mathrm{PC} 2$, and e $4 \mathrm{q} 3$ described $35.8,12.20$, and $8.80 \%$ of the distinction, respectively (Table 8 ). The most noteworthy loadings on PC1 were 1-2, 2-3, 1-4, 1-9, 3-12, 9-10, 4-5, 11-12, 3-10, 3-9, 2-9, 1-11, 8-9, 4-11, 2-12, 12-13, 7-11, 6-9, 3-4, 7-8, 4-9, 4-10, 3-1, 2-11, and 1-2 (Table 8). CVA yielded three canonical variations (CV1, CV2, and CV3) in 35 truss morphometric characters. CV1, CV2, and CV3 accounted for $58.4,27.6$, and $14.0 \%$ of group variability (Table 8). Pooled within-group correlations between canonical variables and CVs showed the following contributions among 35 truss morphometric characters: 22 characters (1-10, 2-3, 1-4, 1-9, 3-12, 9-10, 4-5, 11-12, 3-10, 3-9, 2-9, $1-3,1-11,8-9,10-11,4-11,2-12,12-13,7-11,6-9,6-8$ and 6-10) to CV1; 2 characters (5-6 and 3-4) to CV2; and 11 characters (7-8, 4-9, 4-10, 2-10, 3-11, 6-11, 7-9, 6-7, 2-11, 1-2 and 12-1) to CV3 (Table 8).

TABLE 8. Component loadings of first three principal components (PC) and canonical covariates (CV) for truss morphometric characters in N. nandus collected from Arial Kha river, Madaripur (AKRM); Bohnni baor, Gopalganj (BBG); Nabaganga river, Jhenidah (NRJ) and Dhakuria beel, Jashore (DBJ) in Bangladesh. Character descriptions are given in material and methods section

\begin{tabular}{|c|c|c|c|c|c|c|}
\hline \multirow[b]{2}{*}{ Characters } & \multicolumn{3}{|c|}{ PCA } & \multicolumn{3}{|c|}{ CVA } \\
\hline & PC 1 & PC 2 & PC 3 & CV 1 & CV 2 & CV 3 \\
\hline $1-10$ & 0.829 & -0.299 & 0.115 & $-0.464^{*}$ & 0.140 & 0.078 \\
\hline $2-3$ & 0.709 & -0.425 & -0.233 & $-0.383^{*}$ & 0.080 & 0.229 \\
\hline $1-4$ & 0.750 & -0.384 & 0.248 & $-0.374^{*}$ & 0.165 & -0.066 \\
\hline $1-9$ & 0.753 & -0.394 & 0.319 & $-0.340^{*}$ & 0.177 & -0.059 \\
\hline $3-12$ & 0.860 & 0.028 & 0.143 & $-0.339^{*}$ & 0.081 & 0.059 \\
\hline $9-10$ & 0.819 & -0.137 & -0.184 & $-0.288^{*}$ & 0.005 & 0.087 \\
\hline $4-5$ & 0.680 & -0.331 & -0.343 & $-0.258^{*}$ & 0.046 & 0.200 \\
\hline $11-12$ & 0.791 & -0.127 & -0.077 & $-0.258^{*}$ & 0.047 & 0.100 \\
\hline $3-10$ & 0.733 & 0.247 & 0.045 & $-0.240^{*}$ & 0.027 & 0.035 \\
\hline $3-9$ & 0.786 & -0.184 & 0.359 & $-0.234^{*}$ & 0.223 & 0.046 \\
\hline $2-9$ & 0.731 & 0.197 & -0.056 & $-0.205^{*}$ & -0.064 & 0.100 \\
\hline $1-3$ & -0.461 & 0.574 & 0.243 & $0.192^{*}$ & 0.001 & -0.136 \\
\hline $1-11$ & 0.690 & -0.031 & 0.284 & $-0.188^{*}$ & 0.005 & 0.001 \\
\hline $8-9$ & 0.521 & -0.032 & 0.088 & $-0.186^{*}$ & 0.157 & 0.133 \\
\hline $10-11$ & -0.336 & 0.538 & 0.195 & $0.184^{*}$ & -0.061 & -0.039 \\
\hline $4-11$ & 0.776 & 0.088 & 0.204 & $-0.176^{*}$ & -0.006 & 0.036 \\
\hline $2-12$ & 0.558 & 0.386 & -0.141 & $-0.161^{*}$ & -0.034 & 0.156 \\
\hline $12-13$ & 0.542 & 0.130 & -0.050 & $-0.151^{*}$ & -0.124 & -0.044 \\
\hline $7-11$ & 0.719 & 0.364 & 0.203 & $-0.130^{*}$ & 0.043 & -0.001 \\
\hline $6-9$ & 0.635 & 0.007 & 0.004 & $-0.099^{*}$ & 0.081 & 0.096 \\
\hline $6-8$ & 0.212 & -0.082 & -0.129 & $-0.068^{*}$ & 0.011 & 0.068 \\
\hline $6-10$ & 0.101 & 0.544 & -0.286 & $0.037^{*}$ & -0.012 & 0.022 \\
\hline $5-6$ & -0.237 & 0.300 & 0.289 & 0.169 & $0.231^{*}$ & -0.086 \\
\hline $3-4$ & 0.649 & 0.066 & 0.221 & -0.164 & $0.173^{*}$ & 0.047 \\
\hline $7-8$ & 0.802 & 0.160 & -.158 & -0.242 & 0.052 & $0.321^{*}$ \\
\hline $4-9$ & 0.483 & -0.282 & 0.354 & -0.173 & 0.112 & $-0.297^{*}$ \\
\hline $4-10$ & 0.494 & 0.396 & -0.206 & -0.027 & -0.160 & $0.267^{*}$ \\
\hline $2-10$ & 0.029 & 0.349 & 0.777 & 0.093 & 0.100 & $-0.254^{*}$ \\
\hline $3-11$ & 0.701 & 0.368 & -0.263 & -0.215 & 0.045 & $0.232^{*}$ \\
\hline $6-11$ & -0.138 & 0.155 & 0.803 & 0.082 & -0.001 & $-0.231^{*}$ \\
\hline
\end{tabular}




\begin{tabular}{lcccccc}
$7-9$ & 0.239 & 0.771 & -0.372 & 0.030 & -0.078 & $0.210^{*}$ \\
$6-7$ & 0.126 & 0.399 & 0.499 & 0.059 & 0.153 & $-0.166^{*}$ \\
$2-11$ & 0.579 & 0.553 & -0.303 & -0.077 & -0.129 & $0.141^{*}$ \\
$1-2$ & 0.488 & 0.556 & -0.093 & -0.066 & -0.027 & $0.088^{*}$ \\
$12-1$ & -0.099 & 0.416 & 0.155 & 0.032 & -0.080 & $-0.083^{*}$ \\
Eigenvalue & 12.531 & 4.259 & 3.088 & 7.439 & 3.516 & 1.780 \\
Variance \% & $35.8 \%$ & $12.2 \%$ & $8.8 \%$ & 58.4 & 27.6 & 14.0 \\
Cumulative \% & $35.8 \%$ & $47.9 \%$ & $56.8 \%$ & 58.4 & 86.0 & 100.0 \\
\hline *Largest absolute correlation between each variable and any discriminant function
\end{tabular}

*Largest absolute correlation between each variable and any discriminant function

The biplot arrangements, that is, PC1 versus PC2 and $\mathrm{CV} 1$ versus CV2, of the meristic (Figure 3(a) and 3(d)), morphometric (Figure 3(b) and 3(e)), and truss morphometric (Figure 3(c) and 3(f)) characters were constructed using PCA and CVA results, respectively. The biplot results of the meristic characters demonstrated four multivariate spaces with a significant overlap and unclear differentiation among the four populations (Figure 3(a) and 3(d)). The biplot results of the morphometric characters exhibited four multivariate spaces with a high overlap among the four populations in PC1 versus PC2 (Figure 3(b)) and a slight overlap in the result of CV1 versus CV2 (Figure 3(e)). The biplot results of the truss morphometric characters displayed four multivariate spaces with a slight overlap in PC1 versus PC2 (Figure 3(c)), whereas distinct separation was observed in individuals from the four populations in CV1 versus CV2 (Figure 3(f)). Three dendrograms were constructed on the basis of the complete linkage and Euclidean distance to examine the phenotypic relationships independently among the individuals of the four populations. In the dendrogram, intermingling results were observed in the individuals in meristic characters, and the individuals of the NRJ population mainly contributed as the distinct population (Figure 4(a)). Similarly, individuals were also performed as intermixing stage by using morphometric characters, where BBG population mainly formed as distinct population (Figure 4(b)). Consequently, distinct outcomes were also demonstrated by the individuals in truss morphometric characters, and the DBJ population diverged as a unique distinct population (Figure 4(c)).
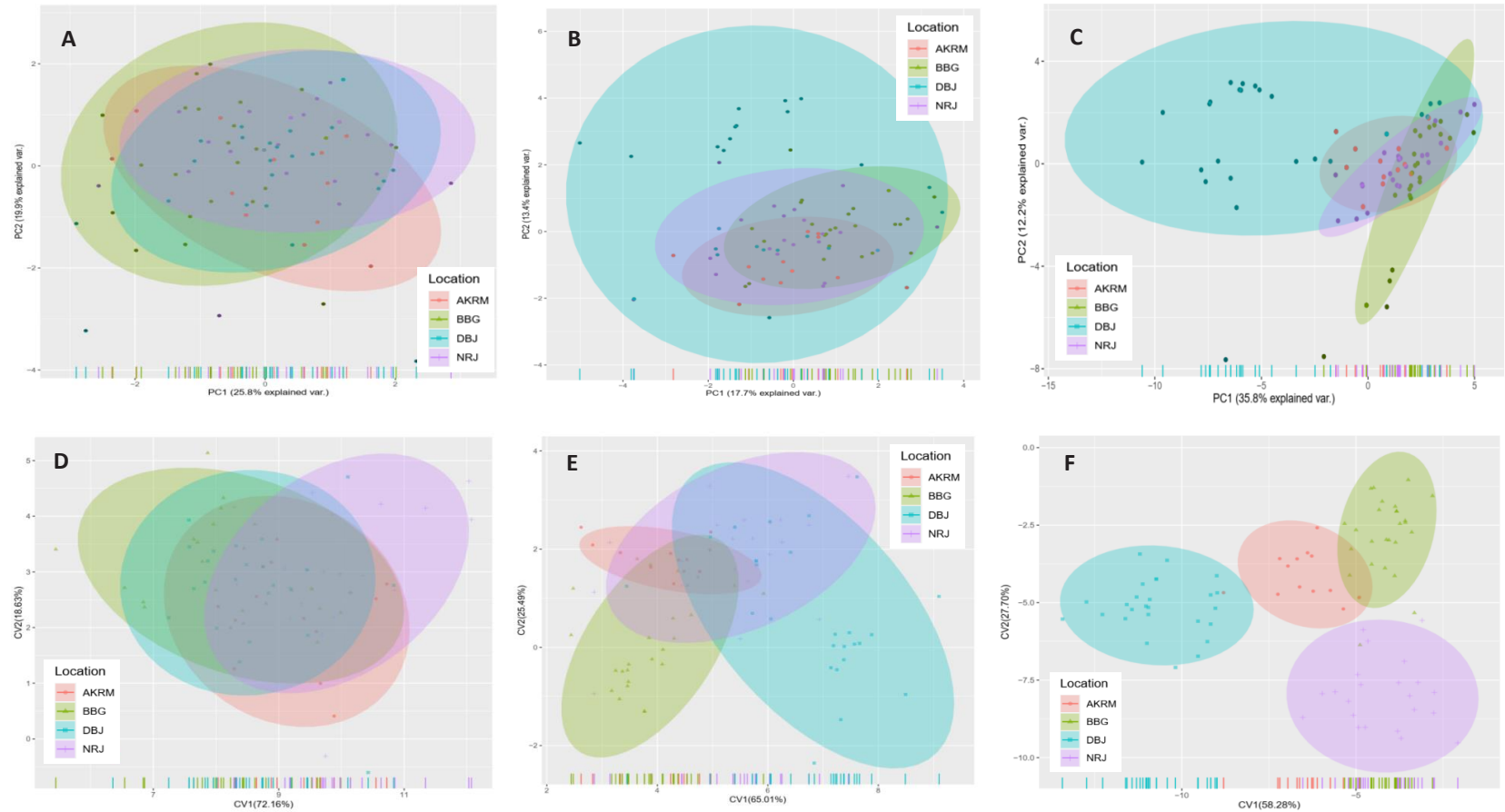

FIGURE 3. (a-c) Principal component analysis, and (d-f) and canonical variate analysis of Nandus nandus obtained from meristic, morphometric, and truss morphometric characters, respectively. Fish samples collected from Arial Kha river, Madaripur (AKRM);

Bohnni baor, Gopalganj (BBG); Nabaganga river, Jhenidah (NRJ) and Dhakuria beel, Jashore (DBJ) in Bangladesh 
A

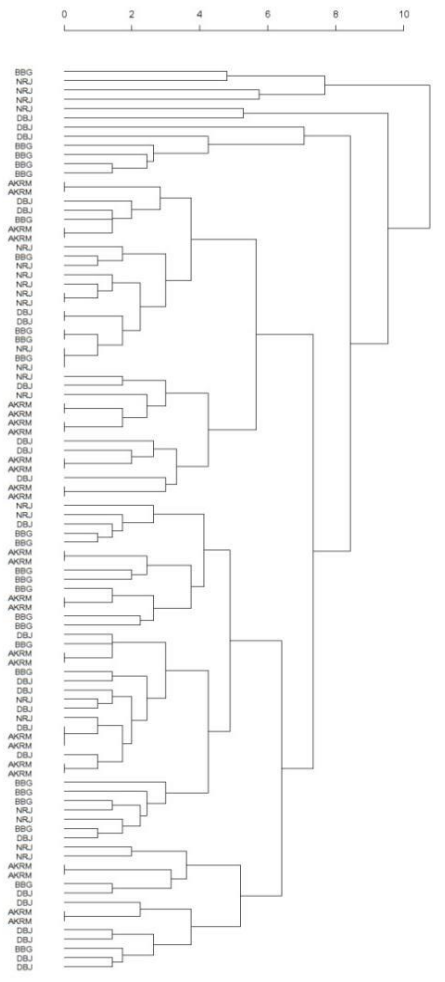

B

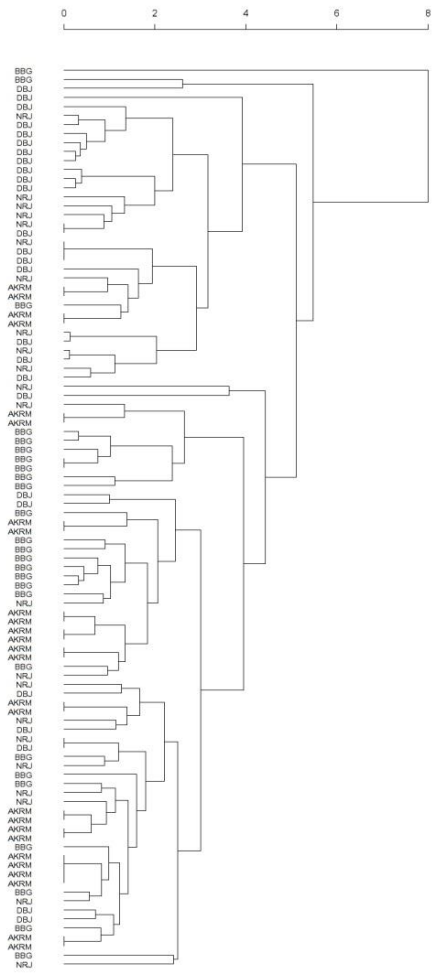

C

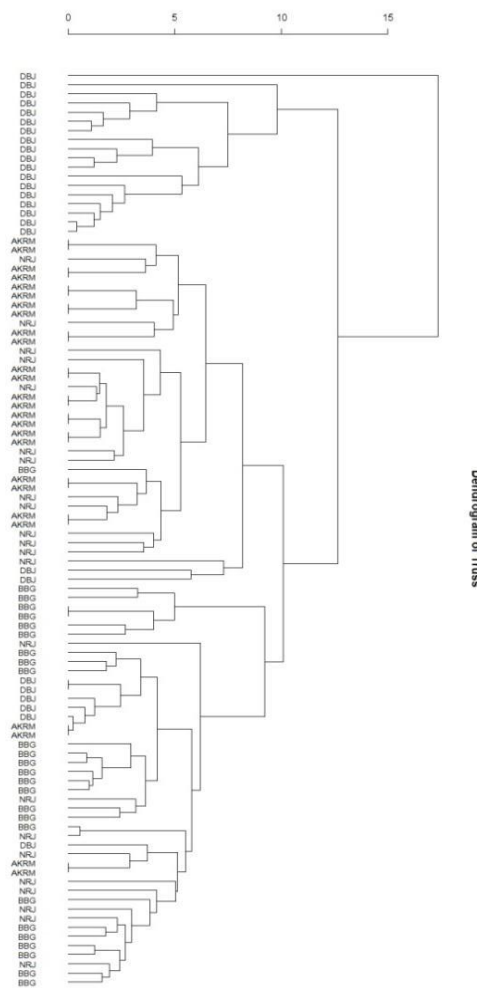

FIGURE 4. Dendrogram with complete linkage and Euclidean distance of meristic, morphometric and truss morphometric data of Nandus nandus: (a) dendrogram derived from meristic data, (b) dendrogram derived from morphometric data, and (c) dendrogram derived from truss morphometric data. Fish samples collected from Arial Kha river, Madaripur (AKRM); Bohnni Baor, Gopalganj (BBG); Nabaganga river, Jhenidah (NRJ) and Dhakuria Beel, Jashore (DBJ) in Bangladesh

\section{DISCUSSION AND CONCLUSION}

Among all vertebrates fishes are one of the most susceptible organisms that pose high environmentally induced morphological dissimilarities. Hence, fishes exhibit maximum phenotypic plasticity among populations of other organisms, even though the same species occupy a single ecological niche (Allendorf 1987; Wimberger 1992). However, our study disclosed the intraspecific phenotypic plasticity of Nandus in a large range from four freshwater ecological sources of Southwestern Bangladesh. Similarly, Goswami and Dasgupta (2007) studied meristic characters and observed that the average numbers of fin rays are in the range of 12-13 for DSFR, 16 for PecFR, 15 for CFR, and 7-9 for AFR. Significant results have also been observed in $N$. oxyrhynchus from the Mekong Basin in Vietnam (Ng et al. 1996), N. prolixus from Northeastern Borneo in Indonesia (Chakrabarty et al. 2006), and N. meni from the Noakhali Coast in Bangladesh (Hossain \& Sarker 2013). The meristic characters used in this research (i.e. DSFR, CFR, AFR, PevFR, and PecFR) could be assigned to conjoined genetic bases and ecological variations that originated in topographical juxtaposition (Saborido-Rey \& Nedreaas 2000; Walsh et al. 2001). Nevertheless, high deviations in PecFR may have been caused by the effect of environmental influences formed at the time of ontogenetic development through pre- or post-fecundation influence (Lindsey 1988). The discrepancy of PecFR may be ascribed to the nature of the number of fin rays, which are static in later stages than other meristic characters over ontogeny (Akbarzadeh et al. 2009). The difference in the number of rays of pectoral fins may be due to the temperature in their ecological niches and feeding modes (Kahilainen \& Østbye 2006; Trabelsi 2002). Conversely, the consequences of individual polymorphism and quantitative genetics on meristic variations are not omitted.

In the present study, the differences in morphometric and truss measurements were highly significant in post hoc tests among the four populations. Such a degree of phenotypic changes among the populations may be due 
to their distinct geographical site, current environmental dissimilarity of the four ecological niches, or different descendants. Generally, fishes and aquatic organisms exhibit high sensitivity to environmental changes and rapidly alter their body shapes with respect to their new environmental conditions for proper adaptation. Phenotypic characters can exhibit high plasticity because of the fluctuation of environmental conditions, such as several abiotic (e.g. temperature, water quality parameters, and climate change) and biotic (e.g. food abundance, host-pathogen-parasite interaction) factors (Allendorf \& Phelps 1988; Solomon et al. 2015; Wimberger 1992;). Usually, fishes are highly vulnerable because of environment-induced morphological variations in comparison with other vertebrate within intra- and interpopulation levels (Allendorf et al. 1987; Wimberger 1992). However, describing the cause of the morphological changes between/among populations (Cadrin 2000) is difficult when certain observed variances are due to growth differences, mortality, and reproduction rates (Silva et al. 2013). The phenotypic plasticity of fish is high because they adapt their physiological characteristics and behavior to environmental changes, and such adaptations eventually alter their morphological traits (Stearns 1983). Morphological alterations in aquatic vertebrates with minimal environmental differences may be difficult to distinguish by studying gross morphometric and meristic characters only. Therefore, truss network dimensions were included in this trial. Turan et al. (2004) indicated that truss network systems are dominant tools in fish stock identification and stock delineation. In the present research, the truss network system might be efficiently used to differentiate the four populations. Highly significant variations were anticipated because of four entirely different ecological niches (i.e. the two rivers are open water habitats, and the two beels are closed water habitats). Ecologically or environmentally persuaded phenotypic discrepancies may be beneficial to the investigation of the stock structure of exploited species, particularly during a short time frame (Gain et al. 2017; Hossain et al. 2010; Mahfuj et al. 2017; Simon et al. 2010).

Phenotypic differentiation in the four populations showed strong overlap according to PCA and CVA results. Morphometric and truss morphometric characters usually play a significant role in the creation of stock discrimination rather as compared to meristic characters. However, in this study, the four wild population could not be separated into individually distinct multivariate spaces judging from the observation of overlap in PCA and the dendrogram with complete linkage. This is contrary to the findings of Okomoda et al. (2018a, 2018b) who reported that the pure and reciprocal crosses Clarias gariepinus and Pangasianodon hypophthalmus can be discriminated using morphological data. This also not in tandem with the finding of Hossain et al. (2010) with Labeo calbasu. Mahfuj et al. (2019a, 2019b, 2019c) detected similar results in Macrognathus pancalus, Xenentodon cancila, and Lepidocephalichthys guntea, respectively. The divergent of wild group based on morphological data has been hypothesized to be formed due to environmental and genetic factors (Allendorf \& Phelps 1988; Nakamura et al. 2003; Okomoda et al. 2018; Solomon et al. 2015). The finding of this study may just attest to similarity of origin of the different wild populations understudied.

The finding of this study are highly useful as a basis for conducting further studies on Nandus populations. For aquaculture and open-water fishery management, the information obtained in this study may be helpful in sorting out superior populations after further studies are performed. More so, further studies, such as genetic research and analysis on the influences of environmental dynamics, are required for the in situ and ex-situ conservation and artificial seed propagation of certain populaces to protect and save this nearly threatened species from extinction.

\section{ACKNOWLEDGEMENTS}

We would like to thank anonymous reviewers for their very useful comments that greatly improved the earlier version of this manuscript. Thanks to UKM for the financial support through the research grant 'GP2019-K019059' and UKM-Sime Darby Foundation Chair in Climate Change Grant 'ZF-2019-003' to the corresponding author.

\section{REFERENCES}

Ahmed, M.S. 2008. Assessment of fishing practices on the exploitation of the Titas floodplain in Brahmanbaria, Bangladesh. Turkish Journal of Fisheries and Aquatic Sciences 8(2): 329-334.

Agarwal, V.P. \& Sharma, K.U. 1966. Studies on the physiology of digestion in Nandus nandus (Ham.). Proceedings of the Indian Academy of Sciences 64: 157-168.

Akbarzadeh, A., Facxsarahmand, H., Shabani, A.A., Karami, M., Kaboli, M., Abbasi, K. \& Rafiee, G.R. 2009. Morphological variation of the pikeperch Sander lucioperca (L.) in the southern Caspian Sea, using a truss system. Journal of Applied Ichthyology 25(5): 576-582.

Allendorf, F.W. \& Phelps, S.R. 1988. Loss of genetic variation in a hatchery stock of cutthroat trout. Transactions of the American Fisheries Society 109(5): 537-543.

Allendorf, F.W., Ryman, N. \& Utter, F. 1987. Genetics and fishery management: Past, present and future in population genetics and fisheries management. In Population Genetics and Fishery Management, edited by Ryman, N. \& Utter, F. Washington: University of Washington Press. pp. 1-20.

Başusta, A., Özer, E.I., Girgin, H., Serdar, O. \& Başusta, N. 2014. Length-weight relationship and condition factor of Hippocampus hippocampus and Hippocampus guttulatus inhabiting Eastern Black Sea. Pakistan Journal of Zoology 46(2): 447-450. 
Cadrin, S.X. 2000. Advances in morphometric identification of fishery stocks. Reviews in Fish Biology and Fisheries 10(1): 91-112.

Cadrin, S.X. \& Friedland, K.D. 1999. The utility of image processing techniques for morphometric analysis and stock identification. Fisheries Research 43(1): 129-139.

Chakrabarty, P., Oldfield, R.G. \& Ng, H.H. 2006. Nandus prolixus, a new species of leaf fish from northeastern Borneo (Teleostei: Perciformes: Nandidae). Zootaxa 1328: 51-61.

Chowdhury, G.W. 2015. Nandus nandus. The IUCN Red List of Bangladesh. Volume 5: Freshwater Fishes. Dhaka: IUCN, International Union for Conservation of Nature, Bangladesh Country Office.

Crispo, E. 2008. Modifying effects of phenotypic plasticity on interactions among natural selection, adaptation and gene flow. Journal of Evolutionary Biology 21(6): 1460-1469.

Das, M. \& Zamal, N. 2000. Domestication of an endangered fish species Nandus nandus (Ham.) pt. 1. Laboratory rearing of young fish up to sexual maturity. Bangladesh Journal of Fisheries Research 4(2): 135-140.

Eklöv, P. \& Svanbäck, R. 2005. Predation risk influences adaptive morphological variation in fish populations. The American Naturalist 167(3): 440-452.

Elliott, N.G., Haskard, K. \& Koslow, J.A. 1995. Morphometric analysis of orange roughy (Hoplostethus atlanticus) off the continental slope of southern Australia. Journal of Fisheries Biology 46(1): 202-220.

Gain, D., Mahfuj, M.S., Huq, K.A., Islam, S.S., Minar, M.H., Goutham-Bharathi, M.P. \& Das, S.K. 2017. Landmark-based morphometric and meristic variations of endangered mrigal carp, Cirrhinus cirrhosus (Bloch 1795), from wild and hatchery stocks. Sains Malaysiana 46(5): 695-702.

Goswami, S. \& Dasgupta, M. 2007. Analysis of the morphometric and meristic characters of the fish Nandus nandus (Hamilton) from the new alluvial zone of West Bengal. Records of the Zoological Survey of India 107: 81-90.

Hamilton, F. 1822. An Account of the Fishes Found in the River Ganges and Its Branches. Uttarakhand: Bishen Singh Mahendra Pal Singh.

Hood, C.S. \& Heins, D.C. 2000. Ontogeny and allometry of body shape in the blacktail shiner, Cyprinella venusta. Copeia 2000(1): 270-275.

Hossain, M.A., Nahiduzzaman, M., Saha, D., Khanam, M.U.H. \& Alam, M.S. 2010. Landmark-based morphometric and meristic variations of the endangered carp, Kalibaus Labeo calbasu, from stocks of two isolated rivers, the Jamuna and Halda, and a hatchery. Zoological Studies 49(4): 556-563.

Hossain, M.S. \& Sarker, S. 2013. New species of leaf fish Nandus meni (Perciformes: Nandidae) from Noakhali, Bangladesh. Zoology and Ecology 23(3): 191-197.

Kahilainen, K. \& Østbye, K. 2006. Morphological differentiation and resource polymorphism in three sympatric whitefish Coregonus lavaretus (L.) forms in a subarctic lake. Journal of Fish Biology 68(1): 63-79.

Kaiser, H.F. 1974. An index of factorial simplicity. Psychometrika 39: 31-36.

Kalhoro, M.A., Liu, Q., Valinassab, T., Waryani, B., Abbasi, A.R. \& Memon, K.H. 2015. Population dynamics of greater lizardfish, Saurida tumbil from Pakistani waters. Pakistan Journal of Zoology 47(4): 921-935.

Kocovsky, P.M., Adams, J.V. \& Bronte, C.R., 2009. The effect of sample size on the stability of principal component analysis of truss-based fish morphometrics. Transaction of American Fisheries Society 138: 487-496.

Langerhans, R.B. 2008. Predictability of phenotypic differentiation across flow regimes in fishes. Integrative and Comparative Biology 48(6): 750-768.

Lindsey, C.C. 1988. 3 factors controlling meristic variation. Fish Physiology. Vol. 11. pp. 197-274. Massachusetts: Academic Press.

Mahfuj, M.S., Khatun, A., Boidya, P. \& Samad, M. 2019a. Meristic and morphometric variations of barred spiny eel Macrognathus pancalus populations from Bangladeshi freshwaters: An insight into landmark-based truss network system. Croatian Journal of Fisheries: Ribarstvo 77(1): 7-18.

Mahfuj, M.S., Rahman, M.M., Islam, M., Samad, M.A., Paul, A.K. \& Adhikary, R.K. 2019b. Landmark-based morphometric and meristic variations of freshwater garfish, Xenentodon cancila from four natural stocks of SouthWestern Bangladesh. Journal of Advanced Veterinary and Animal Research 6(1): 117-124.

Mahfuj, S.E., Rahman, S.U. \& Samad, A. 2019c. Landmarkbased truss morphometrics delineate the stock structure of Lepidocephalichthys guntea. Journal of Fisheries and Aquatic Science 14(1): 25-32.

Mahfuj, S., Ashraful, M.A., Parvez, I., Minar, M.H. \& Samad, A. 2017. Morphological variations of Labeo bata populations (Teleostei: Cyprinidae) in six rivers of Bangladesh: A landmark-morphometric contribution. Iranian Journal of Ichthyology 4(3): 270-280.

McGarigal, K., Cushman, S. \& Stafford, S. 2000. Multivariate Statistics for Wildlife and Ecology Research. New York: Springer Verlag.

Mir, J.I., Sarkar, U.K., Dwivedi, A.K., Gusain, O.P. \& Jena, J.K. 2013. Stock structure analysis of Labeo rohita (Hamilton, 1822) across the Ganga basin (India) using a truss network system. Journal of Applied Ichthyology 29(5): 1097-1103.

Mustafa, G., Ahmed, A.T.A. \& Islam, K.R. 1980. Food, feeding habits and fecundity of a freshwater perch, meni fish. Bangladesh Journal of Agriculture 5(4): 205-210.

Nakamura, T. 2003. Meristic and morphometric variations in fluvial Japanese charr between river systems and among tributaries of a river system. Environmental Biology of Fishes 66(2): 133-141.

Ng, H.H., Vidthayanon, C. \& Ng, P. 1996. Nandus oxyrhynchus, a new species of leaf fish (Teleostei: Nandidae) from the Mekong Basin. The Raffles Bulletin of Zoology 44(1): 11-19.

Okomoda, T.V., Koh, I.C.C., Hassan, A., Amornsakun, T. \& Shahreza, S.M. 2018a. Morphological characterization of the progenies of pure and reciprocal crosses of Pangasianodon hypophthalmus (Sauvage, 1878) and Clarias gariepinus (Burchell, 1822). Scientific Reports 8(1): 1-13.

Okomoda, V.T., Koh, I.C.C., Hassan, A., Amornsakun, T. \& Shahreza, M.S. 2018b. Performance and characteristics of the progenies from the crosses of Pangasianodon 
hypophthalmus (Sauvage, 1878) and Clarias gariepinus (Burchell, 1822). Aquaculture 489(3): 96-104.

Oufiero, C.E. \& Whitlow, K.R. 2016. The evolution of phenotypic plasticity in fish swimming. Current Zoology 62(5): 475-488.

Parsons, K.J., McWhinnie, K., Pilakouta, N. \& Walker, L. 2020. Does phenotypic plasticity initiate developmental bias? Evolution \& Development 22(1-2): 56-70.

Rahman, A.K.A. 2005. Freshwater Fishes of Bangladesh. $2^{\text {nd }}$ ed. pp. 394. Dhaka: University of Dhaka.

Rohlf, F.J. 2006. TPS Software Series. New York: Department of Ecology and Evolution, State University of New York, Stony Brook.

Ross, N., Islam, M.M. \& Thilsted, S.H. 2003. Small indigenous fish species in Bangladesh: Contribution to vitamin A, calcium and iron intakes. The Journal of Nutrition 133(11): 4021S-4026S.

Saborido-Rey, F. \& Nedreaas, K.H. 2000. Geographic variation of Sebastes mentella in the Northeast Arctic derived from a morphometric approach. ICES Journal of Marine Science 57(4): 965-975.

Simon, K.D., Bakar, Y., Temple, S.E. \& Mazlan, A.G. 2010. Morphometric and meristic variation in two congeneric archer fishes Toxotes chatareus (Hamilton 1822) and Toxotes jaculatrix (Pallas 1767) inhabiting Malaysian coastal waters. Journal of Zhejiang University Science B 11(11): 871-879.

Silva, S.E., Silva, I.C., Madeira, C., Sallema, R., Paulo, O.S. \& Paula, J. 2013. Genetic and morphological variation in two littorinid gastropods: Evidence for recent population expansions along the East African coast. Biological Journal of the Linnean Society 108(3): 494-508.

Solomon, S.G., Okomoda, V.T. \& Ogbenyikwu, A.I. 2015. Intraspecific morphological variation between cultured and wild Clarias gariepinus (Burchell) (Clariidae, Siluriformes). Archives of Polish Fisheries 23(1): 53-61.

Stearns, S.C. 1983. A natural experiment in life-history evolution: field data on the introduction of mosquito fish (Gambusia affinis) to Hawaii. Evolution 37(3): 601-617.

Strauss, R.E. \& Bookstein, F.L. 1982. The truss: Body form reconstructions in morphometrics. Systematic Biology 31(2): 113-135.

Svanbäck, R. \& Eklöv, P. 2002. Effects of habitat and food resources on morphology and ontogenetic growth trajectories in perch. Oecologia 131(1): 61-70.

Trabelsi, M. 2002. Le complexe Atherina boyeri. Caractérisation biométrique, biochimique et génétique. Mise en de deux nouvelles espèces d'athérines dans le méditerranéen. Université de Tunis 291.

Turan, C., Yalçin, S., Turan, F., Okur, E. \& Akyurt, I. 2005. Morphometric comparisons of African catfish, Clarias gariepinus, populations in Turkey. Folia Zoologica 54(1/2): 165-172.
Turan, C., Ergüden, D., Gürek, M. \& Turan, F. 2004. Genetic and morphologic structure of Liza abu (Heckel, 1843) populations from the rivers Orontes, Euphrates and Tigris. Turkish Journal of Veterinary and Animal Sciences 28(4): 729-734.

Walsh, M.G., Bain, M.B., Squiers, T., Waldman, J.R. \& Wirgin, I. 2001. Morphological and genetic variation among shortnose sturgeon Acipenser brevirostrum from adjacent and distant rivers. Estuaries 24(1): 41-48.

Webster, M. \& Sheets, H.D. 2010. A practical introduction to landmark-based geometric morphometrics. Quantitative Methods in Paleobiology 16: 168-188.

West-Eberhard, M.J. 1989. Phenotypic plasticity and the origins of diversity. Annual Review of Ecology and Systematics 20(1): 249-278.

Wimberger, P.H. 1992. Plasticity of fish body shape. The effects of diet, development, family and age in two species of Geophagus (Pisces: Cichlidae). Biological Journal of the Linnean Society 45(3): 197-218.

Md. Sarower-E-Mahfuj, Md. Abdus Samad \& Md. Abdul Alim Department of Fisheries and Marine Biosciences Jashore University of Science and Technology Jashore-7408

Bangladesh

Fee Faysal Ahmed

Department of Mathematics

Jashore University of Science and Technology

Jashore-7408

Bangladesh

Yosni Bakar \& Simon Kumar Das*

Department of Earth Sciences and Environment

Faculty of Science and Technology

Universiti Kebangsaan Malaysia

43600 UKM Bangi, Selangor Darul Ehsan

Malaysia

Simon Kumar Das*

Marine Ecosystem Research Center

Faculty of Science and Technology

Universiti Kebangsaan Malaysia

43600 UKM Bangi, Selangor Darul Ehsan

Malaysia

*Corresponding author; email: simon@ukm.edu.my

Received: 12 February 2018

Accepted: 22 May 2020 